\title{
Milk Consumption and Health Beliefs and Its Relation to BMI in College Students
}

\section{Charles Platkin $^{1 *}$, Ming Chin Yeh ${ }^{1}$, Patricia Estrella ${ }^{1}$, Caitlin MacShane ${ }^{1}$, Deborah Allinger ${ }^{1}$, Rebecca Elbaum ${ }^{1}$, Melissa Keeney ${ }^{1}$, Barbara Brumaru' and Katarzyna Wyka ${ }^{1}$}

${ }^{1}$ Nutrition and Food Science Program, Hunter College, School of Urban Public Health, City University of New York School of Public Health, Manhattan, USA

${ }^{2}$ Epidemiology and Biostatistics Program, Hunter College, School of Urban Public Health, City University of New York School of Public Health, Manhattan, USA

\begin{abstract}
Objective: To evaluate milk consumption, its association with Body Mass Index (BMI), and the relationship between health beliefs about milk and it's consumption in college students.

Methods: In 2013, a paper and electronic survey was conducted to assess personal health information, type of milk consumed, its typical serving size, and frequency of consumption. A series of statements pertaining to milk consumption and health was assessed using a five-point Likert. The survey was conducted between May 1 and August 5, 2013 and recruited participants from a multi-ethnic population of students and employees of an urban college.

Results: Participants $(n=553)$ were $66.7 \%$ female, mean age was 23.75 years $(S D=7.40)$ and mean $B M I$ was $23.61(S D=5.11)$. Participants most commonly consumed skim and low-fat milk $(44.9 \%)$ several times a week $(51.7 \%)$ in a serving size of $1 / 2-1$ cup $(68.8 \%)$. Females consumed more milk alternatives $(p=0.003)$, with lower frequently $(p<0.001)$ and in smaller serving sizes $(p=0.025)$. African Americans, Asians and Hispanics reported drinking larger serving sizes compared to other race/ethnic groups $(p=0.011)$. Majority of respondents agreed that milk is good for one's health $(74.5 \%)$, a good source of protein $(62.6 \%)$, a good source of calcium $(87.4 \%)$, and needed for stronger bones $(77.3 \%)$. Significant associations were observed between alternative milk consumption and weaker beliefs in all milk beliefs statements $(p<0.001)$. There were no significant differences between those who reported consuming whole, chocolate or flavored milk and skim or low fat milk. Males more strongly believed that milk is a good source of protein
\end{abstract}

${ }^{*}$ Corresponding author: Charles Platkin, Nutrition and Food Sciences Program, Hunter College, School of Urban Public Health, City University of New York School of Public Health, Silberman Building, 2180 Third Avenue RM 528, New York, NY 10035, USA, Tel: +1 2123967741; E-mail: cplatkin@hunter.cuny.edu

Citation: Platkin C, Yeh MC, Estrella P, MacShane C, Allinger D, et al. (2015) Milk Consumption and Health Beliefs and Its Relation to BMI in College Students. J Obes Weight Loss 1: 002.

Received: November 06, 2015; Accepted: December 08, 2015; Published: December 24, 2015
( $p=0.045$ ) and Whites expressed more disagreement with milk health belief statements. BMI was not associated with milk consumption or health beliefs about milk.

Conclusion: Our findings showed that this group of college age students tended to consume skim or low-fat milk. Gender differences were observed in consumption and health beliefs of milk. No racial/ethnic differences were observed in type of milk consumption, yet groups differed in agreement of milk health belief statements. No association was observed between BMI and type of milk consumption, or between BMI and milk health beliefs. Further research should be conducted to control confounding factors in order to confirm whether milk consumption or health beliefs and BMI are not related.

\section{Introduction}

The worldwide prevalence of overweight and obesity has almost doubled since 1980 [1]. Globally, 3.4 million deaths per year have been attributed to overweight and obesity [2] and is a risk factor for chronic diseases [1]. Consequently, there has been an increased inquiry in prevention mechanisms, such as increasing physical activity and adequate nutrition. The impact of dietary components, such as dairy products on body weight and health status is being actively researched.

\section{Milk Consumption and Health Status}

Milk is a source of lipids, proteins, vitamins and minerals, as well as immunoglobulins, hormones, growth factors, and other bioactive peptides [3]. However, cow's milk also contains additional liquid calories, saturated fat, and cholesterol, which have been demonstrated to contribute to obesity and chronic disease [4]. In the last decade, there has been much controversy regarding the healthfulness of milk and other dairy products. Some investigators have hypothesized that dairy products and calcium may assist in weight loss and decreases of body fat [5-8]. However, this hypothesis is contradicted by additional studies that indicate that dairy products have no effect $[9,10]$.

A diet high in calcium have been demonstrated to decrease intracellular calcium concentrations, activate lipolysis, repress lipogenesis, and subsequently, reduce body fat deposition and increase thermogenesis [11]. In an obese rat model study, a high-calcium diet was shown to retard fat accumulation and weight gain, while the opposite effect was observed in low-calcium diets [12]. Furthermore, a randomized cross-over trial found that a breakfast containing high-calcium, high-vitamin D dairy led to an increase in fat oxidation rate and diet-induced thermogenesis in adults [13].

Other components in dairy products may also play a role in body weight regulation. Conjugated linoleic acid has been shown to reduce body fat accumulation in several animal models [14]. Dairy products also contain bioactive components whose combined efforts with calcium mitigate adiposity [8]. The proteins in dairy products, specifically whey protein in conjunction with bioactive peptides and amino acids, may suppress appetite, increase satiety, and regulate food intake [15].

In a review conducted by Zemel and Miller [7], it was found that in non-caloric restrictive diets that included three or more servings of dairy helped to significantly reduce adiposity in obese humans. 
Furthermore, it has been suggested that increasing calcium or dairy intake may help in the regulation of body weight and possible weight gain [6]. However, a review of prospective cohort studies done by Louie et al., [16] found that the evidence of consuming dairy food for a protective effect on weight status was inconclusive. Similarly, other review studies have found that neither dairy products nor calcium supplementation impact body weight status $[9,17]$.

This study attempts to further clarify the relationship between BMI and milk consumption, focusing on gender and race/ethnic differences and health beliefs about milk. Specifically, the objectives of this study are to evaluate:

1) Milk consumption by gender and race/ethnicity, including milk type, serving size and frequency of milk consumption,

2) The relationship between health beliefs about milk and its consumption and BMI in college students.

\section{Methodology}

\section{Study design and survey development}

The Institutional Review Board for the protection of human participants in research at CUNY Hunter College approved the protocol for this study. Survey questions were developed based primarily on prior studies $[18,19]$. Prior to data collection, a pilot test of 30 participants was conducted to assess the survey quality. Minimal changes were made to the survey, mainly in regards to wording of questions. Since some responses identified more than one ethnicity, a "mixed ethnicity" choice was added. The survey was designed to assess personal health information, milk consumption and milk health beliefs.

\section{Individual characteristics and attributes}

Questions in this section included age, sex, ethnicity, height and weight, household income and health-seeking behavior questions such as smoking status, degree of physical activity and self-perceived healthy eating habits. Self-reported height and weight were used to calculate BMI.

\section{Milk consumption and health beliefs}

Questions in this section pertained to type of milk consumed (i.e., skim milk, low-fat milk, whole milk, etc.), typical serving size, frequency of consumption of milk and other dairy products, and calcium supplement use. This was followed by a series of statements pertaining to milk consumption and health evaluated by a five-point Likert scale ranging from strongly agrees to strongly disagree.

\section{Data collection}

The survey was conducted between May 1 and August 5, 2013 and recruited participants from a multi-ethnic population of students and employees of an urban college in New York City. Research assistants approached students and employees in the dining area and halls to complete a paper survey and verbal consent was obtained from each participant. In addition, an online version of the survey (Appendix 1) was created using Formstack (www.formstack.com), a website dedicated to form creation and online data collection tool. A link to the survey and consent form was distributed to students using listserv emails to different academic departments within the college.

\section{Statistical analysis}

General descriptive statistics (Mean/SD and percentages) were used to describe the sample and assess milk consumption. Chi-square tests with Bonferroni post hoc corrections were conducted to test for differences in milk consumption between males and females and race/ethnic groups (White, African-American, Hispanic, Asian, and Other/Mixed). Mann-Whitney U tests and Kruskal-Wallis tests with Bonferroni post-hoc corrections were used to evaluate gender and race/ethnic differences in eight milk health beliefs assessed using 5 Likert scale questions. To aid with results interpretation, percentages of respondents who indicated agreement with these statements were also reported. The associations between milk consumption and milk health beliefs were assessed using the same methods. Lastly, linear and logistic regressions were conducted to test for associations between BMI index and BMI categories and milk consumption and milk beliefs. All analyses were conducted using the Statistical Package for the Social Sciences (SPSS version 12, SPSS Inc., Chicago IL, 2004). Significance was judged as $\mathrm{p}<.05$ and analyses were not adjusted for inflated Type I error due to testing multiple hypotheses.

\section{Results}

\section{Sample description}

The sample was representative of current college undergraduate students [20] (Table 1). Of the respondents, $66.7 \%$ were female. The mean age was 23.75 years $(\mathrm{SD}=7.40)$. Most identified themselves as White (35.3\%), followed by Asian (22.8\%), Hispanic (19.4\%), other/mixed (14.1\%) and African American (8.3\%). The mean BMI was $23.61(\mathrm{SD}=5.11)$. The majority of respondents were of normal BMI (66.1\%), 17.1\% were overweight, and 9.6\% were obese. Most respondents described their diet as healthy $(57.0 \%)$ and reported exercising at least 1 times a week (64.6\%).

\begin{tabular}{|c|c|c|}
\hline Characteristic & $\mathbf{n}$ & $M(S D)$ or $\%$ \\
\hline Age & 551 & $23.75(7.40)$ \\
\hline \multicolumn{3}{|l|}{ Gender } \\
\hline Male & 182 & 32.7 \\
\hline Female & 371 & 66.7 \\
\hline \multicolumn{3}{|l|}{ Race/ethnicity } \\
\hline White & 195 & 35.3 \\
\hline African-American & 46 & 8.3 \\
\hline Asian & 126 & 22.8 \\
\hline Hispanic & 107 & 19.4 \\
\hline Other/Mixed & 78 & 14.1 \\
\hline \multicolumn{3}{|l|}{ Household Income } \\
\hline$\$ 0-\$ 29,999$ & 174 & 32.8 \\
\hline$\$ 30,000-\$ 49,999$ & 126 & 23.8 \\
\hline$\$ 50,000-\$ 69,999$ & 80 & 15.1 \\
\hline$\$ 70,000$ or more & 150 & 28.3 \\
\hline \multicolumn{3}{|l|}{ Education Level } \\
\hline Some college & 365 & 66.0 \\
\hline College graduate & 188 & 34.0 \\
\hline BMI & 519 & $23.61(5.11)$ \\
\hline Underweight $(\mathrm{BMI}<18.5)$ & 37 & 7.1 \\
\hline Normal $(18.5 \leq \mathrm{BMI} \leq 24.9)$ & 343 & 66.1 \\
\hline Overweight $(25 \leq \mathrm{BMI} \leq 29.9)$ & 89 & 17.1 \\
\hline Obese $(\mathrm{MBI} \geq 30)$ & 50 & 9.6 \\
\hline
\end{tabular}


Citation: Platkin C, Yeh MC, Estrella P, MacShane C, Allinger D, et al. (2015) Milk Consumption and Health Beliefs and Its Relation to BMI in College Students. J Obes Weight Loss 1: 002 .

\begin{tabular}{|c|c|c|}
\hline Smoking Status & & \\
\hline Non smoker & 443 & 79.7 \\
\hline Former smoker & 60 & 10.8 \\
\hline Current smoker & 51 & 9.2 \\
\hline Exercise & & \\
\hline Rarely & 130 & 35.4 \\
\hline 1-2 times per week & 102 & 27.8 \\
\hline 3 or more times per week & 135 & 36.8 \\
\hline Diet & & \\
\hline Healthy & 306 & 57.0 \\
\hline Neither healthy nor unhealthy & 146 & 27.2 \\
\hline Unhealthy & 85 & 15.8 \\
\hline \multicolumn{2}{|c|}{ Table 1: Sample characteristics. } \\
\hline
\end{tabular}

Milk consumption overall and by gender and race/ethnicity

The majority of respondents reported consuming milk (87.5\%). The most common type of milk consumed was skim/low fat-milk (44.9\%), followed by whole milk, chocolate or flavored milk (35.5\%) and milk alternatives (19.6\%). Sixty-nine percent of respondents consumed a serving size of $1 / 2-1$ cup and the remaining respondents consumed milk in beverages (31.3\%). About half of the participants reported consuming milk several times per week (51.7\%) and 18.3\% consumed milk daily. Other dairy products were consumed with a similar frequency (several times a week $61.3 \%$ and daily $24.0 \%$ ) (Table 2).

There were significant gender differences in type of milk consumed, serving size and frequency, with females preferring milk alternatives $\left(23.3 \%\right.$ vs. $\left.12.2 \%, \chi^{2}(1, \mathrm{~N}=482)=11.37, \mathrm{p}=0.003\right)$, smaller serving size $\left(1 / 2-1\right.$ cup $65.7 \%$ vs. $75.8 \%, \chi^{2}(1, N=473)$ $=5.05, \mathrm{p}=0.025$ ), and less frequent milk consumption (daily $15.9 \%$ vs. $\left.31.9 \%, \chi^{2}(1, \mathrm{~N}=478)=20.77, \mathrm{p}<0.001\right)$. The use of calcium supplements and other dairy products was not statistically different between genders (Table 2).

The lowest consumption of whole milk, chocolate, or flavored milk was reported by Whites (28.4\%), followed by Hispanics (35.8\%), other/mixed (38\%), African Americans (40.5\%) and Asians (41.8\%), however, these differences were not statistically significant (Table 2). Likewise, there were no statistically significant differences in frequency of milk consumptions, however African Americans, Asians and Hispanics reported drinking $1 / 2-1$ cup more often than Whites and Other/Mixed race/ethnic groups $\left(\chi^{2}(1, \mathrm{~N}=473)=13.01, \mathrm{p}=0.011\right)$.

\section{Beliefs about milk and milk consumption}

Beliefs about milk are reported in Table 3. The majority of respondents agreed that milk is:

1) Good for one's health (74.5\%), 2) A good source of protein (62.6\%), 3) A good source of calcium (87.4\%), and 4) is needed for stronger bones $(77.3 \%)$.

Much lower endorsement rates were observed for statements regarding skim milk being healthier than whole or low-fat milk $(42.8 \%)$ and the importance to consume the recommended 3 servings of dairy per day (43.5\%). Lastly, fewer than a quarter of respondents agreed with the statement that drinking milk helps prevent heart disease (23.6\%) and that milk helps with weight loss (16.2\%). Notably, respondents who consumed skim/low-fat milk or milk alternatives generally reported a higher level of disagreements with all statements. Statistically significant associations were observed between consuming milk alternatives and weaker beliefs in all milk statements (all $p<0.001$ ). There were no significant differences between those who reported consuming whole, chocolate or flavored milk and skim or low fat milk.

Beliefs about milk were similar among females and males regarding all statements (all $\mathrm{p}>0.05$ ), except that males expressed a stronger belief that milk is a good source of protein $(U=18465.5$, $\mathrm{p}=0.045)$ and that milk helps with weight loss $(\mathrm{U}=27486.5$, $\mathrm{p}=0.071)$.

Racial/ethnic differences in milk health beliefs were the strongest regarding statements about milk being good for one's health $\left(\chi^{2}(4, \mathrm{~N}\right.$ $=367)=18.83, \mathrm{p}=0.001)$, whether milk helps with weight loss $\left(\chi^{2}\right.$ $(4, \mathrm{~N}=523)=13.62, \mathrm{p}=0.009)$, whether skim milk is healthier than whole milk or low-fat milk $\left(\chi^{2}(4, \mathrm{~N}=449)=10.80, \mathrm{p}=0.029\right)$, and whether it is important to consume the recommended 3 servings of dairy per day $\left(\chi^{2}(4, \mathrm{~N}=468)=28.20, \mathrm{p}<0.001\right)$. Pairwise comparisons revealed that Whites generally reported more disagreement with all statements, particularly in contrast to:

1) African-Americans and Hispanics regarding milk being good for one's health, 2) Asians and Other/Mixed regarding milk helping with weight loss, 3) Hispanics regarding the belief that skim milk is healthier than whole milk or low-fat milk, 4) Hispanics and Asians regarding the importance to consume the recommended 3 servings of dairy per day (all $\mathrm{p}<0.05$ ).

\section{BMI and milk consumption and milk health beliefs}

Milk consumption was not associated with BMI or BMI category, with similar percentages of individuals within BMI categories reporting whole, chocolate, or flavored milk consumption with similar frequency and serving size. Likewise, no statistically significant associations between milk health beliefs and BMI were found.

\section{Discussion}

\section{Milk consumption, milk health beliefs and BMI}

In response to the obesity epidemic, the 2010 Dietary Guidelines for Americans (DGA) recommends that adults consume three servings of low-fat or skim milk as an alternative to reduced fat (2\%) or whole milk [21]. Currently in the United States, the majority of fluid milk intake comes from reduced fat or whole milk [21]. Likewise, approximately $46 \%$ of New York City adults consume reduced fat or whole milk, while $36 \%$ consume skim or low-fat milk [22]. In contrast, the participants of this study consumed more skim and low-fat milk than whole and flavored milk, which has been corroborated in other studies as college students' preferred choice $[23,24]$. Additionally, participants' milk consumption frequency was lower than the recommended dietary dairy intake of 3 servings per day with the most common consumption occurring several times a week [21]. This finding is consistent with previous studies showing a declining dairy intake or inadequate intake among young adults [23-26].

In this study, no significant racial/ethnic differences were observed in the type of milk consumed. This was in contrast to other studies 
Citation: Platkin C, Yeh MC, Estrella P, MacShane C, Allinger D, et al. (2015) Milk Consumption and Health Beliefs and Its Relation to BMI in College Students. J Obes Weight Loss 1: 002.

\begin{tabular}{|c|c|c|c|c|c|c|c|c|c|c|}
\hline & $\begin{array}{l}\text { Overall } \\
n=553\end{array}$ & $\begin{array}{c}\text { Male } \\
n=182\end{array}$ & $\begin{array}{c}\text { Female } \\
n=371\end{array}$ & & $\begin{array}{l}\text { White } \\
\mathrm{n}=195\end{array}$ & $\begin{array}{c}\text { African-American } \\
n=46\end{array}$ & $\begin{array}{c}\text { Hispanic } \\
\mathrm{n}=107\end{array}$ & $\begin{array}{l}\text { Asian } \\
\mathrm{n}=126\end{array}$ & $\begin{array}{c}\text { Other/Mixed } \\
n=78\end{array}$ & \\
\hline & $\%$ & $\%$ & $\%$ & $p$-value ${ }^{c}$ & $\%$ & $\%$ & $\%$ & $\%$ & $\%$ & $p$-value ${ }^{d}$ \\
\hline Don't drink milk & 12.5 & 9.4 & 13.8 & 0.009 & 12.9 & 19.6 & 11.2 & 11.3 & 9 & 0.295 \\
\hline Type of milk usually consumed & & & & 0.003 & & & & & & 0.331 \\
\hline $\begin{array}{l}\text { Whole milk/Chocolate or flavored } \\
\text { milk }\end{array}$ & 35.5 & 43.3 & 31.1 & & 28.4 & 40.5 & 35.8 & 41.8 & 38 & \\
\hline $\begin{array}{l}\text { Skim milk/Low fat milk/ Milk } \\
\text { alternative }\end{array}$ & 39.4 & 44.5 & 45.6 & & 47.3 & 43.2 & 49.5 & 41.8 & 40.8 & \\
\hline Milk alternatives ${ }^{a}$ & 19.6 & 12.2 & 23.3 & & 24.3 & 16.2 & 14.7 & 16.4 & 21.1 & \\
\hline Typical serving size & & & & 0.025 & & & & & & 0.011 \\
\hline $1 / 2$ cup - 1 cup & 68.8 & 75.8 & 65.7 & & $60.0^{\mathrm{a}}$ & $81.1^{\mathrm{b}}$ & $74.2^{\mathrm{b}}$ & $75.9^{b}$ & $64.3^{\mathrm{a}}$ & \\
\hline In beverages (i.e. coffee, tea) & 31.3 & 24.2 & 34.3 & & 40 & 18.9 & 25.8 & 24.1 & 35.7 & \\
\hline Frequency milk drinking & & & & $<.001$ & & & & & & 0.614 \\
\hline Daily & 18.3 & 31.9 & 15.9 & & 25.7 & 18.9 & 21.1 & 20.2 & 15.7 & \\
\hline Several times a week & 51.7 & 55.8 & 60 & & 52.1 & 64.9 & 63.2 & 59.6 & 62.9 & \\
\hline Rarely & 30 & 12.3 & 24.1 & & 22.2 & 16.2 & 15.8 & 20.2 & 21.1 & \\
\hline Calcium supplement & & & & 0.1 & & & & & & 0.673 \\
\hline Yes & 14.5 & 10.8 & 16.3 & & 13.8 & 19.4 & 11 & 10.6 & 12.1 & \\
\hline Other dairy products ${ }^{b}$ & & & & 0.855 & & & & & & \\
\hline Daily & 24 & 25.1 & 23.4 & & 35.5 & 25 & 21.1 & 15.6 & 21.1 & $<.001$ \\
\hline Several times a week & 61.3 & 59.8 & 62.2 & & 58 & 52.8 & 69.5 & 63.3 & 66.2 & \\
\hline Rarely & 14.7 & 15.1 & 14.4 & & 6.5 & 22.2 & 9.5 & 21.1 & 12.7 & \\
\hline
\end{tabular}

Table 2: Milk consumption overall and by gender and race/ethnicity.

Note: a: Milk alternatives include products such as soy, almond, rice and coconut milk,

b: Other dairy products include cheese, yogurt, ice cream, butter, cottage cheese and cream cheese,

$c, d$ : $p$-values for gender differences and race/ethnic differences were based on bivariate $2 \times 2 x^{2}$ tests with Bonferroni correction. Pair wise comparisons with different alphabetical subscripts differ significantly $(p<.05)$ (bolded)

\begin{tabular}{|c|c|c|c|c|c|c|c|c|c|c|c|c|c|c|c|}
\hline \multirow[b]{2}{*}{ Statement } & \multicolumn{2}{|c|}{$\begin{array}{c}\text { Overall } \\
n=553\end{array}$} & \multicolumn{2}{|c|}{ Male $n=182$} & \multicolumn{2}{|c|}{ Female $n=371$} & \multicolumn{2}{|c|}{ White $n=195$} & \multicolumn{2}{|c|}{$\begin{array}{l}\text { African-Amer- } \\
\text { ican } n=46\end{array}$} & \multicolumn{2}{|c|}{$\begin{array}{c}\text { Hispanic } \\
\mathrm{n}=107\end{array}$} & \multicolumn{2}{|c|}{ Asian $n=126$} & \multirow{2}{*}{$\begin{array}{c}\begin{array}{c}\text { Other/ } \\
\text { Mixed } \\
\mathbf{n}=78\end{array} \\
\text { Mean rank }\end{array}$} \\
\hline & $\begin{array}{l}\% \\
\text { Yes }\end{array}$ & $\begin{array}{l}\% \\
\text { Yes }\end{array}$ & $\begin{array}{c}\text { Mean } \\
\text { rank }\end{array}$ & $\begin{array}{l}\% \\
\text { Yes }\end{array}$ & $\begin{array}{c}\text { Mean } \\
\text { rank }\end{array}$ & $\begin{array}{l}\% \\
\text { Yes }\end{array}$ & $\begin{array}{c}\text { Mean } \\
\text { rank }\end{array}$ & $\begin{array}{l}\% \\
\text { Yes }\end{array}$ & $\begin{array}{c}\text { Mean } \\
\text { rank }\end{array}$ & $\begin{array}{l}\% \\
\text { Yes }\end{array}$ & $\begin{array}{c}\text { Mean } \\
\text { rank }\end{array}$ & $\begin{array}{l}\% \\
\text { Yes }\end{array}$ & $\begin{array}{c}\text { Mean } \\
\text { rank }\end{array}$ & $\begin{array}{l}\% \\
\text { Yes }\end{array}$ & \\
\hline Milk is good for your health & 74.5 & 75.5 & 191.4 & 75.7 & 180.1 & 63.9 & $206.0^{\mathrm{a}}$ & 86.4 & $150.6^{b}$ & 85 & $158.8^{\mathrm{b}}$ & 79.8 & $173.7^{\mathrm{ab}}$ & 76.6 & $190.0^{\mathrm{ab}}$ \\
\hline Milk helps with weight loss & 16.2 & 17.8 & 246.7 & 15.8 & $270.1^{*}$ & 11.3 & $290.7^{\mathrm{a}}$ & 15.2 & $239.5^{\text {ab }}$ & 15.1 & $258.1^{\text {ab }}$ & 21.8 & $243.5^{\mathrm{b}}$ & 22.1 & $237.8^{b}$ \\
\hline $\begin{array}{l}\text { Milk is a good source of } \\
\text { protein }\end{array}$ & 62.6 & 71.1 & 205.8 & 59.1 & 229.6 & 57.5 & 237.4 & 69.6 & 199.4 & 59.4 & 228.1 & 67.7 & 210.6 & 70.1 & 205.1 \\
\hline $\begin{array}{l}\text { Drinking milk helps prevent } \\
\text { heart disease }\end{array}$ & 23.2 & 24 & 255.7 & 23.6 & 249.5 & 19.5 & 270.9 & 15.2 & 260 & 21.7 & 234 & 29.8 & 233.5 & 29.9 & 247.4 \\
\hline $\begin{array}{l}\text { Milk is a good source of } \\
\text { calcium }\end{array}$ & 87.4 & 88.3 & 153.2 & 89.1 & 148.5 & 87 & 149.9 & 89.1 & 151.3 & 87.7 & 152.7 & 91.8 & 145.1 & 89.6 & 153.5 \\
\hline $\begin{array}{l}\text { Milk is needed for stronger } \\
\text { bones }\end{array}$ & 77.3 & 78.3 & 158.8 & 77.2 & 158.4 & 69.6 & 169.4 & 80.4 & 150.1 & 81 & 151.7 & 86.8 & 140.3 & 75 & 169.6 \\
\hline $\begin{array}{l}\text { Skim milk is healthier than } \\
\text { whole or low-fat milk }\end{array}$ & 42.8 & 42.1 & 225.6 & 44.7 & 225.5 & 40.3 & $244.4^{a}$ & 40 & $232.5^{\mathrm{ab}}$ & 51.9 & $196.5^{b}$ & 46 & $213.2^{\mathrm{ab}}$ & 38.7 & $231.0^{\mathrm{ab}}$ \\
\hline $\begin{array}{l}\text { It is important to consume } \\
\text { the recommended } 3 \text { serv- } \\
\text { ings of dairy per day }\end{array}$ & 43.5 & 46.1 & 233.3 & 43.3 & 235.8 & 33.7 & $272.4^{a}$ & 45.7 & $219.2^{\mathrm{ab}}$ & 45.3 & $216.7^{b}$ & 54.1 & $195.7^{\mathrm{b}}$ & 52.6 & $227.2^{\mathrm{ab}}$ \\
\hline
\end{tabular}

Table 3: Beliefs about milk overall and by gender and race/ethnicity.

Note: Lower rank = more agreement with the statement; \% agree was computed by collapsing "Strongly Agree" and "Agree" response categories; Significance tests used were Mann-Whitney $\mathrm{U}$ test for gender comparisons and Kruskal-Wallis $\mathrm{H}$ test for race/ethnicity comparisons categorical data with Bonferroni correction; Pairwise comparisons with different alphabetical subscripts differ significantly $(p<0.05)\left(\right.$ bolded); ${ }^{*} p=0.071$. 
that found that Whites consumed more low-fat dairy products than other racial/ethnic groups and other racial/ethnic groups consumed more high-fat dairy products $[27,28]$. Furthermore, we found that African-Americans, Asians, and Hispanics consumed more milk in serving sizes of $1 / 2-1$ cup compared to Whites or other groups, which is in contrast to other studies that found intake to be greater among Whites [29-32].

Significant gender differences were also observed in terms of type of milk preference, serving size and frequency of consumption. Females consumed more milk alternatives and in smaller serving sizes compared to males. This is in contrast to other studies that found no significant gender differences in non-milk drinkers and milk drinkers [33]. We also found females consumed milk less frequently than men, which has been seen in other studies [34,35]. In fact, Hiza and Gerrior [36] found that women consumed significantly less servings of milk than men did (1.3/day vs 1.6/day). Additionally, a cross-sectional study done by Touvier et al., [37] found that $36.2 \%$ of men vs $26.5 \%$ of women were more likely to exceed the 3 -a-day dairy recommendation, however, only $35 \%$ of the participants did meet the recommendation.

In this study, participants believed that milk was beneficial for one's health, good source of calcium, good source of protein, and needed for stronger bones, which has been seen in other studies [38-41]. Overall, there was a trend for greater disagreement on whether milk prevented heart disease, helps with weight loss, skim milk being healthier than whole milk or low-fat milk, and the importance of consuming 3 servings of dairy per day. Participants who chose milk alternatives significantly believed less in all milk belief statements compared to other milk drinkers, which is in contrast to studies that found that non-dairy milk were viewed as more beneficial and more likely to prevent disease [38]. Although statistically insignificant, participants who consumed whole, chocolate, or flavored milks believed in previous statements more strongly. Participants may view that these milks as more wholesome as observed in an intervention study conducted by Weiss and colleagues, whose participants indicated whole milk's higher healthfulness by referring to it as "vitamin D" milk [42].

We found gender and racial/ethnic differences in milk health beliefs. Compared to males, females significantly disagreed that milk is a good source of protein. In contrast, a cross-sectional study found men to be less convinced of milk's nutritional benefits and women having more positive belief of milk's health benefits [43]. Yet, other studies have shown no differences between genders in perceptions of milk's beneficial health benefits [38]. There was a stronger disagreement amongst Whites compared to other racial/ethnic groups to whether milk was good for one's health, helped with weight loss, skim milk being healthier than whole milk or low-fat milk, or the importance of consuming 3 servings of dairy per day.

This study did not find a significant link between milk consumption, regardless of its fat content, and BMI in urban college students. Likewise, this null association between dairy consumption and BMI has been observed in cross-sectional studies [26,44,45], prospective studies [46-49] and randomized controlled trials [50]. This is in contrast to previous studies that have found an inverse association with dairy consumption and BMI [51,52] or even a positive association [53].

The literature on the relationship between dairy fat intake and BMI or body fat composition has yielded inconsistent results. In a cross-sectional study conducted by Murphy et al., [54] dairy food intake, mainly reduced fat milk, was inversely associated with BMI in overweight/obese adults. Conversely, a review done by Kratz et al., [55] determined that high-fat dairy consumption was associated with favorable weight outcomes, while low-fat dairy consumption was positively correlated with weight gain. It is possible we did not observe any effects on BMI due to the low dairy intake, as reasoned by the authors of a cross-sectional study of college-aged Japanese adults [45] or other BMI-confounding factors not assessed in this study.

This study also found no relationship between milk beliefs and $\mathrm{BMI}$ indicating that milk health beliefs may not predict the outcome of BMI. In one study using the theory of reasoned action to predict milk consumption in women, the authors reasoned that behavior of drinking milk was a combination of intention, beliefs and sensory evaluation with intention and behavior having the highest correlation [56]. However, they pointed out that there is a more complex thought process involved in drinking lower-fat milks [56]. It is reasonable to assume there is a more complex interaction between BMI and milk consumption that we were not able to capture in this study. Furthermore, one should note that most dairy-weight loss research is conducted on overweight/obese subjects, while our population may be more concerned with weight maintenance.

\section{Limitations}

Findings from this study are limited to urban, young college students. Some college employees were recruited in this study; yet, the employee population is less than $11 \%$ of the total college population and should not detrimentally affect the results. During data collection, no option was given to identify the consumption of different types of non-dairy milk or vegetarian status. Also, the use of two different forms of surveys may lead to information bias. Furthermore, there is a chance of misreporting of consumption by participants that may have weakened associations. Surveys can be subjected to an over or underestimation of serving sizes as well as a social desirability bias [57], which been observed to be evoked in similar magnitude in paper and electronic surveys [58]. Another limitation can be the possibility of underestimation of self-reported weight and overestimation of height $[59,60]$. Yet, some studies have shown that the self-reported body weight and heights of young adults tend to be fairly accurate [61,62]. Moreover, relevant confounding factors, such as energy intake or physical activity, may be responsible for the relationship between milk consumption with BMI.

\section{Conclusion}

In conclusion, college age students tend to consume skim or low-fat milk, but below the DGA recommended servings. Gender differences were observed females preferring milk alternatives and disagreeing with certain milk health belief statements. No racial/ethnic differences were observed in type of milk consumption, yet Whites disagreed with particular milk health belief statements. Overall, college age students believed that milk was beneficial for one's health; however, participants who consumed milk alternatives expressed a higher disagreement with all milk health belief statements. There was no association between BMI and type of milk consumption, or between BMI and milk health beliefs. Further research should take steps to control confounding factors, such as physical activity or energy intake, to confirm whether the type of milk consumption and $\mathrm{BMI}$ are not related. 
Citation: Platkin C, Yeh MC, Estrella P, MacShane C, Allinger D, et al. (2015) Milk Consumption and Health Beliefs and Its Relation to BMI in College Students. J Obes Weight Loss 1: 002.

\section{References}

1. World Health Organization (2014) Global status report on non-communicable diseases 2014. World Health Organization, Geneva, Switzerland.

2. Lim SS, Vos T, Flaxman AD, Danaei G, Shibuya K, et al. (2013) A comparative risk assessment of burden of disease and injury attributable to 67 risk factors and risk factor clusters in 21 regions, 1990-2010: A systematic analysis for the global burden of disease study 2010. The Lancet 380: 2224-2260.

3. Haug A, Høstmark AT, Harstad OM (2007) Bovine milk in human nutrition--a review. Lipids Health Dis 6: 25.

4. Livingstone KM, Lovegrove JA, Givens DI (2012) The impact of substituting SFA in dairy products with MUFA or PUFA on CVD risk: Evidence from human intervention studies. Nutr Res Rev 25: 193-206.

5. Davies KM, Heaney RP, Recker RR, Lappe JM, Barger-Lux MJ, et al. (2000) Calcium intake and body weight. J Clin Endocrinol Metab 85: 4635-4638.

6. Parikh SJ, Yanovski JA (2003) Calcium intake and adiposity. Am J Clin Nutr 77: 281-287.

7. Zemel MB, Miller SL (2004) Dietary calcium and dairy modulation of adiposity and obesity risk. Nutr Rev 62: 125-131.

8. Zemel MB, Donnelly JE, Smith BK, Sullivan DK, Richards J, et al. (2008) Effects of dairy intake on weight maintenance. Nutr Metab (Lond) 5: 28.

9. Barr SI (2003) Increased dairy product or calcium intake: is body weight or composition affected in humans? J Nutr 133: 245-248.

10. Huang TT, McCrory MA (2005) Dairy intake, obesity, and metabolic health in children and adolescents: knowledge and gaps. Nutr Rev 63: 71-80.

11. Shi H, Dirienzo D, Zemel MB (2001) Effects of dietary calcium on adipocyte lipid metabolism and body weight regulation in energy-restricted aP2-agouti transgenic mice. FASEB J 15: 291-293.

12. Zhang R, Zhu W, Du X, Xin J, Xue Y, et al. (2012) S100A16 mediation of weight gain attenuation induced by dietary calcium. Metabolism 61: 157-163.

13. Ping-Delfos WCS, Soares M (2011) Diet induced thermogenesis, fat oxidation and food intake following sequential meals: Influence of calcium and vitamin D. Clin Nutr 30: 376-383.

14. DeLany JP, West DB (2000) Changes in body composition with conjugated linoleic acid. J Am Coll Nutr 19: 487-493.

15. Jakubowicz D, Froy O (2013) Biochemical and metabolic mechanisms by which dietary whey protein may combat obesity and type 2 diabetes. J Nutr Biochem 24: 1-5.

16. Louie JC, Flood VM, Hector DJ, Rangan AM, Gill TP (2011) Dairy consumption and overweight and obesity: a systematic review of prospective cohort studies. Obes Rev 12: 582-592.

17. Lanou AJ, Barnard ND (2008) Dairy and weight loss hypothesis: an evaluation of the clinical trials. Nutr Rev 66: 272-279.

18. California Department of Public Health (2012) Compendium of surveys for nutrition education and obesity prevention. The Network for a Healthy California, California Department of Public Health, California, USA.

19. Parmenter K, Wardle J (1999) Development of a general nutrition knowledge questionnaire for adults. Eur J Clin Nutr 53: 298-308.

20. CUNY IRDB (2012) Table 14: Undergraduate students profile, fall 2007 to fall 2012. Hunter college, CUNY, New York, USA.

21. McGuire S (2011) US Department of Agriculture and US Department of Health and Human Services, Dietary Guidelines for Americans, 2010. 7th edition, Washington, DC: US Government Printing Office, January 2011. Adv Nutr 2: 293-294.

22. Centers for Disease Control and Prevention (CDC) (2007) Brief number 0906, milk consumption New York state adults 2007. Behavioral risk factor surveillance system survey, Department of Health and Human Services, Centers for Disease Control and Prevention, Atlanta, Georgia, USA.
23. Georgiou C, Betts N, Hoerr S, Keim K, Peters P, et al. (1997) Among young adults, college students and graduates practiced more healthful habits and made more healthful food choices than did nonstudents. J Am Diet Assoc 97: 754-759.

24. Kolodinsky J, Harvey-Berino JR, Berlin L, Johnson RK, Reynolds TW (2007) Knowledge of current dietary guidelines and food choice by college students: Better eaters have higher knowledge of dietary guidance. J Am Diet Assoc 107: 1409-1413.

25. Larson NI, Neumark-Sztainer D, Harnack, L, Wall M, Story M (2009) Calcium and dairy intake: Longitudinal trends during the transition to young adulthood and correlates of calcium intake. J Nutr Educ Behav 41: 254-260.

26. Poddar KH, Hosig KW, Nickols-Richardson SM, Anderson ES, Herbert WG et al. (2009) Low-fat dairy intake and body weight and composition changes in college students. J Am Diet Assoc 109: 1433-1438.

27. Pereira MA, Jacobs Jr DR, van Horn L, Slattery ML, Kartashov Al, et al. (2002) Dairy consumption, obesity, and the insulin resistance syndrome in young adults: The CARDIA study. Jama 287: 2081-2089.

28. Wang ML, Lemon SC, Olendzki B, Rosal MC (2013) Beverage-consumption patterns and associations with metabolic risk factors among low-income latinos with uncontrolled type 2 diabetes. J Acad Nutr Diet 113: 1695-1703.

29. Debate RD, Topping M, Sargent RG (2001) Racial and gender differences in weight status and dietary practices among college students. Adolescence 36: 819-833.

30. Deshmukh-Taskar P, Nicklas TA, Yang S, Berenson GS (2007) Does food group consumption vary by differences in socioeconomic, demographic, and lifestyle factors in young adults? The Bogalusa heart study. J Am Diet Assoc 107: $223-234$

31. Fulgoni V, Huth $P$, DiRienzo D, Miller G (2004) Determination of the optimal number of dairy servings to ensure a low prevalence of inadequate calcium intake in Americans. J Am Nutr 23: 651-659.

32. Storey ML, Forshee RA, Anderson PA (2006) Beverage consumption in the US population. J Am Diet Assoc 106: 1992-2000.

33. Bus AE, Worsley A (2003) Consumers' health perceptions of three types of milk: a survey in Australia. Appetite 40: 93-100.

34. Dicker D, Belnic Y, Goldsmith R, Kaluski DN (2008) Relationship between dietary calcium intake body mass index, and waist circumference in MABAT - the Israeli national health and nutrition study. Israel Medical Association Journal 10: 512-515.

35. Liebman M, Propst K, Moore S, Pelican S, Holmes B, et al. (2003) Gender differences in selected dietary intakes and eating behaviors in rural communities in Wyoming, Montana, and Idaho. Nutrition Research 23: 991-1002.

36. Hiza H, Gerrior SA (2002) Using the interactive healthy eating index to assess the quality of college students' diets. Family Economics and Nutrition Review 14: 3 .

37. Touvier M, Mejean C, Kesse-Guyot E, Vergnaud A, Hercberg S, et al. (2011) Sociodemographic and economic characteristics associated with dairy intake vary across genders. J Hum Nutr Diet 24: 74-85.

38. Bus AE, Worsley A (2003) Consumers' sensory and nutritional perceptions of three types of milk. Public Health Nutr 6: 201-208

39. Gulliver P, Horwath CC (2001) Assessing women's perceived benefits, barriers, and stage of change for meeting milk product consumption recommendations. J Am Diet Assoc 101: 1354-1357.

40. Jung ME, Mistry C, Bourne JE, Perrier M, Ginis KAM, et al. (2014) A qualitative investigation of adults' perceived benefits, barriers and strategies for consuming milk and milk products. Health Education Journal.

41. Thompson JL, Gerard PD, Drake MA (2007) Chocolate milk and the Hispanic consumer. J Food Sci 72: 666-675.

42. Weiss S, Davis E, Wojtanowski AC, Foster GD, Glanz K, et al. (2015) Consumer taste tests and milk preference in low-income, urban supermarkets. Public Health Nutrition 18: 1419-1422. 
Citation: Platkin C, Yeh MC, Estrella P, MacShane C, Allinger D, et al. (2015) Milk Consumption and Health Beliefs and Its Relation to BMI in College Students. J Obes Weight Loss 1: 002.

43. Wham CA, Worsley A (2003) New Zealanders' attitudes to milk: implications for public health. Public Health Nutr 6: 73-78.

44. Mitsui T, Kasezawa N, Goda T (2007) Milk consumption does not affect body mass index but may have an unfavorable effect on serum total cholesterol in Japanese adults. Nutrition Research 27: 395-399.

45. Murakami K, Okubo H, Sasaki S (2006) No relation between intakes of calcium and dairy products and body mass index in Japanese women aged 18 to 20 y. Nutrition 22: 490-495.

46. Noel SE, Ness AR, Northstone K, Emmett P, Newby PK (2011) Milk intakes are not associated with percent body fat in children from ages 10 to 13 years. J Nutr 141: 2035-2041.

47. O'Neil CE, Nicklas TA, Liu Y, Franklin FA (2009) The impact of dairy product consumption on nutrient adequacy and weight of Head Start mothers. Public Health Nutr 12: 1693-1701.

48. Phillips S, Bandini L, Cyr H, Colclough-Douglas S, Naumova E, et al. (2003) Dairy food consumption and body weight and fatness studied longitudinally over the adolescent period. Int J Obes Relat Metab Disord 27: 1106-1113.

49. Rajpathak SN, Rimm EB, Rosner B, Willett WC, Hu FB (2006) Calcium and dairy intakes in relation to long-term weight gain in US men. Am J Clin Nutr 83: 559-566.

50. Palacios C, Bertrán JJ, Ríos RE, Soltero S (2011) No effects of low and high consumption of dairy products and calcium supplements on body composition and serum lipids in Puerto Rican obese adults. Nutrition 27: 520-525.

51. Abreu S, Santos R, Moreira C, Santos PC, Vale S, et al. (2012) Milk intake is inversely related to body mass index and body fat in girls. Eur $\mathrm{J}$ Pediatr 171: $1467-1474$

52. Moore LL, Singer MR, Qureshi MM, Bradlee ML (2008) Dairy intake and anthropometric measures of body fat among children and adolescents in NHANES. J Am Coll Nutr 27: 702-710.
53. Samara A, Herbeth B, Ndiaye NC, Fumeron F, Billod S, et al. (2013) Dairy product consumption, calcium intakes, and metabolic syndrome-related factors over 5 years in the STANISLAS study. Nutrition 29: 519-524.

54. Murphy KJ, Crichton GE, Dyer KA, Coates AM, Pettman TL, et al. (2013) Dairy foods and dairy protein consumption is inversely related to markers of adiposity in obese men and women. Nutrients 5: 4665-4684.

55. Kratz M, Baars T, Guyenet S (2013) The relationship between high-fat dairy consumption and obesity, cardiovascular, and metabolic disease. Eur J Nutr 52: 1-24.

56. Brewer JL, Blake AJ, Rankin SA, Douglass LW (1999) Theory of Reasoned Action predicts milk consumption in women. J Am Diet Assoc 99: 39-44.

57. Macdiarmid J, Blundell J (1998) Assessing dietary intake: Who, what and why of under-reporting. Nutr Res Rev 11: 231-253.

58. Dodou D, De Winter J (2014) Social desirability is the same in offline, online, and paper surveys: A meta-analysis. Computers in Human Behavior 36: $487-$ 495.

59. Pursey K, Burrows TL, Stanwell P, Collins CE (2014) How accurate is webbased self-reported height, weight, and body mass index in young adults? J Med Internet Res 16: 4

60. Yoong SL, Carey ML, D’Este C, Sanson-Fisher RW (2013) Agreement between self-reported and measured weight and height collected in general practice patients: A prospective study. BMC Med Res Methodol 13: 38.

61. Kuczmarski MF, Kuczmarski RJ, Najjar M (2001) Effects of age on validity of self-reported height, weight, and body mass index: Findings from the third national health and nutrition examination survey, 1988-1994. J Am Diet Assoc 101: 28-34.

62. Quick V, Byrd-Bredbenner C, Shoff S, White AA, Lohse B, et al. (2015) Concordance of self-report and measured height and weight of college students. J Nutr Educ Behav 47: 94-98. 